\title{
A Phenomenological Case Study of Blind Male Masseuses Experiencing Sexual Assault: Implication for Nursing Practice
}

\author{
Nur Setiawati Dewi ${ }^{1 *}$ (D) , Monika Steffi Novia Sabatini ${ }^{1}$ D, Ervia Kusumaningrum ${ }^{1} \mathbb{D}$, Heru Agus Santoso $^{2}$ (D) \\ ${ }^{1}$ Department of Nursing, Faculty of Medicine, Universitas Diponegoro, Semarang, Indonesia; ${ }^{2}$ Department of Informatics, \\ Faculty of Computer Science, Universitas Dian Nuswantoro, Semarang, Indonesia
}

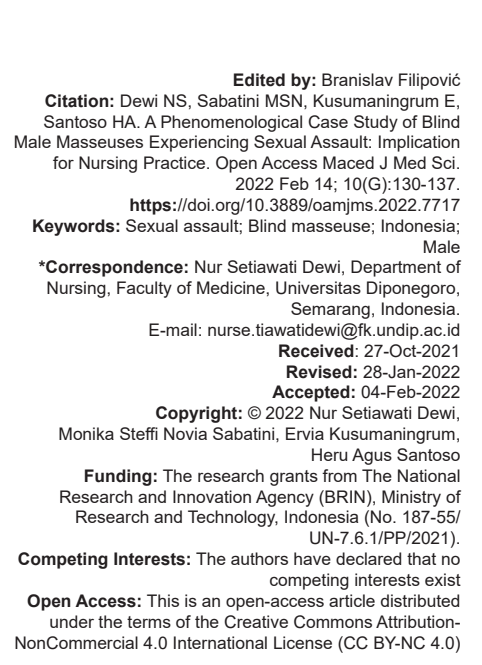

Abstract

BACKGROUND: Having experience of sexual assault may bring a great impact on the lives of blind male masseuses. However, a deep understanding of the consequences is currently still not largely explored.

AIM: The purpose of this study was to explore the experience of sexual assault and the consequences of sexual assaults incidents which occurred in the lives of blind male masseuses.

METHODS: This study used a phenomenological case study design. Interviews were conducted with nine blind male masseuses who had experienced sexual assault while carrying out their profession in Semarang city, Indonesia. The data were analyzed using Giorgi analysis.

RESULTS: The experience of being sexually assaulted disrupts almost all of the participants' lives for a relatively long period of time, and even it is still felt at the present. To release and reduce the fear and trauma caused by sexual assault, the participants consciously drew themselves closer to God as the main thing to do. A prayer to God to be protected from being the victim of sexual assault is a participant's devotion while carrying out their worship ritual. Talking to other blind masseuses also helps them to find the solutions needed to rebuild their lives. However, the participants tend to feel ashamed and reluctant to convey how such sexual assault has affected their lives to present time.

CONCLUSION: Even though the participants have adapted and rebuilt their lives, the residue of sexual assault impact is still felt and remains for a long time. Self-protection training and assistive devices for blind masseuses to prevent the recurrence of sexual assault are significantly important and should be considered to be implemented by nurses.

\section{Introduction}

In global, at least 1.1 billion people belong to the visually loss group, including 43 million of the blind people and the others are those whose low to severe level vision impairment. [1]. The prevalence of blind and visually impaired in Indonesia is 3.0\% of the total population. The majority of blind people come from low socio-economic backgrounds, have low formal education, and most of them work in informal sector [2]. Therefore, they tend to have limitations in choosing jobs that suit their limited conditions. One of the professions mostly chosen by blind people is to become a massage therapist. However, this work has its own consequence as blind masseuses are more vulnerable to sexual assault due to the masseuse's intense physical contact with their customers while they work.

Sexual assault can be defined as any form of harassment including rape and/or forced sexual acts [3], [4]. Studies concerning sexual assault occurred in the visually impaired have found physical, psychological and social problems as some of the consequences of these events. A study from Zegeye in Addis Ababa found that blind women experiencing sexual assault have physiological consequences including lack of sleep, nightmares, headaches and poor appetite [5]. Psychological consequences of sexual harassment which arise include irritability, fear, phobias, depression, and risk of suicide [5], [6], [7]. Moreover, victims of sexual assault also experience problems in relational relationships such as the emergence of negative thoughts towards others, feelings of suspicion towards others, and difficulty in establishing relationships with others [5], [7]. However, the experience of sexual assault and its impact on blind men are still not explored yet, especially to blind men who work as masseuses.

The purpose of this study was to explore the sexual assault incident experienced by blind male masseuses and to describe the impact of the sexual assault on their lives. 


\section{Methods}

\section{Research design}

This study employed a phenomenological-case study as the research design. The researchers choose phenomenological to understand life experiences about what people know, what people feel, and how people experience their world [8], [9]. We selected this approach to capture the unique experience so that we could better understand the context of the lifelong stress felt by blind male masseuse associated with their sexual assault experience. Because this phenomenon was explored through the detailed account of blind male masseuses, a case study approach to phenomenology was appropriate [10]. A phenomenological case studies were conducted to highlight the unique qualities of the individuals in certain contexts [11].

\section{Recruitment}

We recruited nine blind male masseuses in Semarang city, Indonesia using purposive and snowball sampling techniques. All participants were Muslims. Three of them ranged from 24 to 30 years of age, 4 people were 31 to 40 -years-old and the remaining participants were 41 to 55 -years-old. Five of the participants graduated from senior high school, 1 participant had a bachelor degree and the remaining of them graduated from junior high school. In addition, the inclusion criteria of the participants included: 1 ) adult men aged 24-55 years old; 2 ) have experienced sexual assault during work.

\section{Data collection}

Due to the COVID-19 pandemic, researchers conducted the interview with 3 participants through WhatsApp calls, while the other six by direct interviews. Thus, the data collected for this study were from informal conversations. Participants were reassured that they could skip any questions which they felt uncomfortable with, particularly those regarding their sexual assault experiences or other negative things they have experienced. In addition, the researcher also ensured that there were no sanctions if the participants stopped the interview at any time due to the feeling of discomfort. The researchers and the participants used a mixture of Indonesian and Javanese languages in the interviews. In addition, the interviews were recorded on a mobile phone, where the data obtained were then stored in a password protected and encrypted computer file. Once this audio recording has been transcribed, it was then destroyed, and the transcript file is stored on a password protected computer. Participants' anonymity was guaranteed by removing any identifiers from the interview transcripts and giving them the initials $P$ followed by the participant's number.

\section{Data analysis}

Phenomenology analysis was conducted by Giorgi's analysis focusing on comprehensive reports from the perspective and experiences of the individuals, i.e., the participants. Phenomenology research aims to organize information in such a way that experiences give meaning to participant's life [12].

The first stage started by identifying and reviewing all statements of sexual experience, responses to assault, and ways to build resilience after being a victim of sexual assault across various periods of time and circumstances in order to understand the context. Next, data analysis was carried out and conceptualized into a unit of meaning. The meaning units were classified in which the theme emerged. The research theme emerged as the salient experiences of the nine participants through the specific experiences they described and the meaning behind the experience of sexual assault. Finally, the essential structure of individual experience was formed from emerged themes [12], [13].

\section{Ethical consideration}

The study was conducted according to the guidelines of the Declaration of Helsinki, and approved by the Ethics Committee of the Faculty of Medicine, Universitas Diponegoro, Indonesia (363/EC/ KEPK/FK-UNDIP/XI/2021). Since this study involved vulnerable people (blind male masseuses), verbal consent was provided by blind male masseuses and written consent by their guardians. The informed consent contained information that the participation in the study was voluntary. Participants were allowed to withdraw without any consequences and confidentiality was kept strictly.

\section{Results}

This research resulted in three main themes, i.e.: 1) Disturbed life; 2) Drawing themselves closer to Allah (God) to release their fear and trauma; and 3) Willing to share their experiences with others, but are reluctant to reveal the impact caused by the traumatic experience on their lives.

\section{Theme 1: Disturbed life}

Participants said that the first time they experienced sexual assault they felt shock and horrified. The shock response experienced has caused several manifestations in their body such as shaking hands as if they were unable to move. In addition, after experiencing sexual assault, the participants locked 
themselves in their rooms, did not want to eat and drink, were easily anxious, their minds were often blank, had a fever, could not sleep well, and got nightmare since the assault experience was always in their memory. Accordingly, for some time, the participants did not want to accept any customers.

"I was shaking, I couldn't move, because I wasn't married before., My hand was pulled to her genital ...My finger touched her (female) genitals... it was empty that came to my mind after that... as a human, I can remember clearly. It was already 1 month and I have not recovered yet. I had 3 days of fever, couldn't sleep as the thoughts of sexual assault always came to my mind..." (P2)

"It is horrified. He touched our intimate body part..." (P1)

"I felt shock. She asked about porn, like how to have sex, how strong I am during sex, and how many times a day I have sexual intercourse." (P6)

However, the participants realized that this condition was something they had to face so that the participants tried to survive and get through all the bad experiences they had and tried to rebuild their life as usual as before the incident. However, there are some persistent changes that the participants felt as a result of the sexual assault they experienced, for example, participants often refuse to accept foreign customers, except for those recommended by their masseuse friends. If the participant is alone at home, he will refuse to massage when there is a customer comes. Participants also refuse to massage outside their homes for they fear of the assault recurrence. In addition, after being abused, the feelings of suspicion toward strangers and anxiety while doing their job still remains until today. Participant says his sense of smell has become so sharp. He even believes that after the assault, he can tell which person aiming to truly get a massage or those whose bad intentions only by the smell of his prospective customer's sweat.

"....it (assault) is unavoidable. That's a risk which I must face as a masseuse. The point is that you have to endure ... you have to be strong and able to get through it. I need money to live. So, it is inevitably that I have to work again." (P5)

"If I don't know the person or there is no recommendation from a friend, I refuse him/ her." (P1)

"...usually the smell (of the perpetrator) has a strange smell of sweat. As I have experienced it is like powder but stings, the smell is strange... it's different in my opinion." (P2)

"After that incident (assault) I immediately locked myself in my room, scared. I'm still often anxious, suspicious... If no one is home, I choose not to accept patients. After all, there must be someone at home when I accept customer." (P9)

However, P3 has a different response when experiencing sexual assault. P3 responds shocked and angry with the customers. However, P3 is grateful that he survived a more severe sexual assault because of his firm attitude and strong principles. After experiencing sexual assault, according to P3, maintaining a firm attitude and having strong principles had a positive impact on P3. Until now, P3 has not ever received physical sexual assault anymore, but verbal sexual assault is still common. P3 stated that as long as there is no physical contact, according to him, there is no need to worry. However, the participant admitted that after the incident, he became more selective in choosing the customers and tended to limit services outside his house.

"Yes, you have to be firm and have principles. Otherwise, we will be the victims. I don't want to be the victim... luckily nothing happened yesterday. He (the customer) was new, spoke, and asked for this (a kind of genitalia). It's already big... If it's just talking (erotic words), I usually don't take it seriously, but if it's different. Yes, I usually affirm him that I purely do a health massage and nothing else...I become more selective about my prospective patients. Now I don't accept job outside my house, only a few." (P3)

If $\mathrm{P} 3$ is forced to accept customer who comes directly to his house without any prior information or recommendation, he will ask the customer to talk first in order to research his potential/prospective customer in the living room. When the participant finds any discrepancies about the attitudes and communications of his potential customer, the participant usually tries to politely refuse the customer.

"Yes, I chat with him first, ask his name, occupation and others... from there I will know who he is. if he speaks strangely, I will refuse. Don't massage him. I usually give him a logical reason, so that he won't be offended." (P3)

\section{Theme 2: Drawing themselves closer to} Allah (God) to release their fear and trauma

Participants realize that being a masseuse contains the risk of encountering naughty customers. As Muslims, all participants believe that by getting themselves to Allah, God the Almighty, is an effort they can do to avert the negative effects of sexual assault. Some of the things they do to get closer to Allah include: istighfar (multiplying to seek forgiveness of Allah), doing dhuha prayers (additional or supererogatory morning prayers) and other sunnah prayers (additional prayers). 
Some participants perform tahajjud (additional or supererogatory night prayers) asking for protection from Allah. Thus, the participants feel that after prayers the fear or their trauma due to sexual assault gradually decreases.

"For months I still often imagine the incident of sexual assault which I experienced. I also read a lot of istighfar, do dhuha and tahajjud prayers. Thank God, by doing this, my trauma and fear gradually disappear even though it does not vanish completely." (P7)

P4 says that he immediately sunnah prayer after the sexual assault incident. Accordingly, before starting to work, they always take the time to dhuha prayer asking for their work goes well and to avoid all negative things during work such as sexual assault. The participants realize that he has limitations so he just put all his matters to Allah the almighty.

"I immediately prayed sunnah (after the incident). Every morning I do dhuha prayer to avoid unwanted things, like naughty customers and others. I'm blind, so I can only rely on God's grace." (P4)

$\mathrm{P} 6$ revealed that the incident of sexual assault he experienced might be a warning for him to draw himself closer to Allah because he often forgets to carry out his obligation as a Muslim, i.e., do 5 obligatory prayers 5 times a day.

"Perhaps what happened to me (sexual assault) was a warning for me to get closer to Allah. I often forget to pray, I frequently put more priority to my clients and other worldly businesses. When I experienced that (sexual assault), no one helped me. I felt like God was knocking me directly on my head and telling me about who has almighty power over me." (P6)

Theme 3: Willing to share their experiences with others, but are reluctant to reveal the impact caused by the traumatic experience on their lives

After experiencing sexual assault, participants often shared their experiences with fellow masseuses who were also blind, but they limited sharing their experiences with close neighbors. Participants reasoned that sharing with their fellow professionals would provide a solution to get rid of the trauma they experienced. They revealed that the details shared with their colleagues were what behaviors carried out by the perpetrators of sexual assault. Although some of their colleagues gave negative reinforcement, they tried to ignore the comments because they already knew the character of the person with whom they are sharing the experience.

"I don't even talk much with people outside my profession, as the feedback will be different. I share only with those from similar profession because maybe they have the same experience. Hence, the input is more relevant. If I share with my neighbors, they do not experience it." (P6)

"I told my colleague from $A$ to $Z$, but my friend bullied me instead... why didn't you call me. If I were gay, I would tell some friends that I was sure." (P8)

Besides sharing with professional friends, participants also told their wives about the sexual assault they experienced. Participants argued that although the participants did not get a solution from their partners, they felt the burden of assault was slightly reduced by telling the story to their partners.

"Yes, because I have a wife, I will tell everything to my wife... even though I don't get a solution from my wife, but at least I feel a little relief in my heart... lost a little burden." (P5)

However, the participant felt that sexual assault was a disaster and a disgrace so that the impact that appeared on him as the consequences of the sexual assault they experienced tended to be kept as a secret. The participant thought that other people did not need to know about the negative experiences he experienced. Furthermore, he also feels that a man does not need to reveal all his problems to others.

\begin{abstract}
"... as a man I have to be strong, this is a disaster and a disgrace, so it is not necessary for everyone to know about the calamity which be fell me and what happened to me as a result of it (sexual assault)." (P4)
\end{abstract}

\section{Discussion}

The sexual assault experienced by participants included being forced to touch the perpetrator's private body parts (such as genital), stating sexual comments and the perpetrator intentionally touching the private body parts of the participants. This is in line with definition of sexual assault by the WHO, i.e., any sexual act, attempt to obtain a sexual act, unwanted sexual comments or seduction against a person by sexually force, by anyone regardless of their relationship with the victims, under any circumstances, including but not limited to home and work [14].

As a result of such sexual assault, the participants mostly expressed their shocked and fear feelings. Some even showed trauma of such experience. This study also describes how these sexual assault incidents have a negative impact both physically and psychologically to the victims. The participants locked themselves in their rooms, did not 
want to eat and drink, were easily anxious, could not sleep well, had nightmares, and developed excessive suspicion to strangers. These results are in line with previous studies stating that visually impaired victims experience physical dan psychological problems due to the sexual assault they experience [15]. Physiological consequences include sleep deprivation (lack of sleep), nightmares, eating disorders, headaches and poor appetite [16], [17], [18], [19]. Moreover, psychological consequences of sexual assault that arise include irritability (easy to get angry), feelings of fear, and phobias [19], [20]. Some studies also explained the emergence of distrust, shame, guilt, low self-esteem, confusion, isolation, and hopelessness [15], [18], [20], [21], [22]. After being the victims of sexual assault, they may experience severe homophobic reactions to other men [23]. In extreme cases, the victims will experience paranoia which may develop chronic disabilities such as agoraphobia [20], [23]. In addition, trauma impact can be seen in low self-esteem, high levels of anxiety, depression, drugs abuse, being an alcoholic, sexual risk taking, lack of intimacy, PTSD, and suicidal behavior [5], [6], [7], [15], [18], [19], [20], [21], [22]. Other studies have mentioned long-term problems of male victims including sexual dysfunction and difficulty in relationships [20], [23]. This specifically occurs in heterosexual male victims, such as experiencing a loss of gender identity and confusion about sexual orientation as the impact arising due to sexual harassment [23]

Our findings also show that the experiences of sexual assault experienced by blind masseuses interfere with the work and more broadly with the participants' lives suddenly, widespread, and enduring, in almost all aspects of their daily life; but the participants said that they must immediately rise from the slump due to the sexual assault they experienced. However, the participants realized that something had changed in the way they interacted with other people and their environment. The findings of this study add to the evidence that there are changes and consequences to the lives of victims post-sexual assault [24], [25], [26], [27], [28], [29].

To eliminate the trauma of sexual assault, as Muslims, some participants establish a relationship with Allah, the almighty God, through salat (fardh/obligatory and sunnah prayers) and dhikr (remembrance of God). Salat (prayer) is the second most essential of the fundamental acts of worship known as the five pillars of Islam and must be performed daily according to the requirements of Islamic law [30], [31]. The prayer includes several raka'ats which involve standing, raising and lowering the arms, bowing, sitting on the shins, prostrating, and rotating the head. The movement in salat is coordinated with reciting praying and ritual of repeated movements [30], [32]. Overall, the five obligatory prayers consisting of 17 raka'ats involve 280 movements, 72 prostration, and 36 bowing.
Meanwhile, the sunnah (additional) prayer is a prayer ritual that is recommended to be carried out but they are not mandatory. Dhikr is Islamic meditation-based practice to remember of Allah that involves repeating one of Al-Asmaul Husna (Allah's Divine Names/ Attributes) or recitation (utterances) guided through Hadith (a collection of all the utterances and deeds of the Prophet Muhammad PBUH) [31], [32]. The Qur'an commands Muslims to remember Allah throughout the day and night. In addition, prayer is an integral part of dhikr as well as in living a pious life [31], [32]. Yucel's quantitative study stated that salat and dhikr can improve the quality of life such as reducing stress and depression, providing comfort, reducing anxiety, and providing a basis for solving life's difficulties [33].

The study that finds religion as a healing factor in survivors of sexual abuse states that religion and spirituality play an important role in overcoming trauma. Religiosity has been found to foster hope and increase resilience of sexual abuse victims [34]. It is considered an important element to overcome the trauma. Religiosity can provide space for survivors to own and to help them rebuild their sense of identity. Essentially, being religious helps survivors of sexual assault in making meaning; it is a well-known method to cope with trauma [35]. Involvement in spiritual practices and beliefs can also help survivors of sexual assault redefine and rebuild their identity apart from sexual assault [36].

Participants felt that support, from fellow masseuses and partners, is considerably needed to release the trauma. From fellow masseuses, the participants can get solutions or information to prevent sexual attack recurrence. Social support is considered as a source of coping obtained from their significant others, such as family members, friends, and co-workers [37]. Social support also acts as an individual buffer from maladaptive behavior and stress [38]. It also acts as a protective factor against negative outcomes, such as anxiety, depression, dissociative identity disorder, and post-traumatic stress disorder [37], [39], [40], [41], [42], [43], [44], [45]. However, the participants in this study intensely limited the information shared with other people. Some participants were in fact bullied when they shared their experiences of sexual harassment with their friends of the same profession. Meanwhile, the participants hoped they would receive help/information from their professional friends so that the harassment would not be repeated. This result is consistent with previous research showing that the barrier to seeking medical assistance can come from the closest environment; thus, many sexual assault victims do not tell others or seek help after experiencing some sexual assaults [21], [22], [37], [46]. Bullying as well as stereotypes related to myths which largely develop in the community or even exclusion for victims of sexual harassment causes the victims to be more closed and tend to hide the incidents of sexual 
assault they have experienced [23]. Male victims face tough challenges related to the myth of masculinity of which the belief or knowledge is widely held in the community that rape of men is rare and rape of men only occurs in prisons [23]. The community assumes that men are strong individuals and must be able to fight the sexual assault perpetrators [22]. Due to this existing myth, male victims are more likely to be blamed than the perpetrators of abuse [22], [23], [47], [48]. Furthermore, additional suffering was experienced by heterosexual male victims, that the public perception judged that the masculinity of sexual harassment victims was reduced after the incident [48]. Such judgment from the community leads heterosexual male victims to often blame themselves and to experience uncertainty regarding their self-identity and sexual orientation [47], [48]. On the other hand, women in some countries face tough the myth of female virginity that is a symbol of chastity and self-respect [49]. If women have been tainted, the community will accuse them of being naughty and worthless women [50].

\section{Implication for nursing practice}

This research contributes to the field of nursing science by providing a deep understanding of blind male masseuses' lives that have experienced sexual assault. In particular, the researchers explore the sexual assault experienced and the consequences and natural life changes of blind male masseuses following the sexual assault.

This research also has implications for nursing practice where nurses need to develop a sexual assault prevention program for blind masseuses who either have not ever or have ever experienced sexual assault. Socialization about forms of sexual assault through health education for blind masseuses is very important to increase the knowledge and awareness for this group to avoid any sexual assault. In addition, nurses can provide self-protection training for this group so that they feel safe and comfortable while carrying out their profession. Program of reducing the risk of sexual assault should include training for blind masseuses on how to detect and to protect themselves from unwanted sexual intercourse.

In addition, the development and the use of assistive devices for blind masseuses as a preventive tool so that sexual assault will not occur need to be well considered. There are several opportunities in nursing informatics field for the development of assistive technology for blind masseuses. Collaboration with other professions (e.g., computer programmers, engineers) in the development of assistive devices can be carried out where nurses play a role to support the comfort of the blind group during the process of technology development. Consideration from nurses is highly required because nurses are in an essential position to help blind masseuse groups learn to use assistive devices and to support the comfort of this group in adopting the technology.

For the victims of sexual assault, nurses must identify the chronic physical and psychosocial problems experienced by the victims. This identification is necessary to develop the appropriate nursing programs for victims of sexual assault among blind masseuses. Resilience enhancement programs and spiritual therapy may be considered. The resilience program is expected to increase the resilience of sexual assault victims so that they are able to return to positively living their lives. Besides, spiritual therapies (e.g., salat and dhikr) are worth considering since spiritual intervention plays a role in strengthening a person from his inner self so that the individuals are able to support themselves to rise from their sufferings. However, this intervention must consider the limitations which exist in visually impaired group. Nurses should take media or methods that are compatible with this group into account.

The development and/or application of a hot line nursing service that is friendly to people with disabilities can contribute to a significantly essential benefit and role to provide an immediate support to victims after any incident of sexual assault, such as reducing the direct impact of the sexual harassment, increasing the capacity of victims to effectively deal with crisis, increasing the victims' understanding of sexual assault which they experienced and the possible longterm impact of the harassment, establishing safety resource, and providing alternative legal/medical options for the victims.

\section{Limitation of the study}

This study used a single research design, i.e., qualitative approach which has not yet provided quantitative data information as a form to measure the physical and mental health of male victims such as trauma, depression, and/or anxiety due to any sexual assault. This can be considered as a limitation of the study.

\section{Conclusion}

There are chronic psychological problems faced by the victims of sexual assault. The efforts done to rise and live normal lives as what they do before the incident are carried out on the basis of religion and sharing with professional friends. However, the impact of sexual assault is still felt by the victims of such sexual assault. Nurses need to consider providing self-protection training as sexual assault prevention programs. In addition, it is necessary to establish collaboration with the other profession to develop some assistive devices for blind masseuses as a preventive effort so that the sexual assault will not ever reoccur in 
the future.

\section{References}

1. World Health Organization. Blindness and Vision Impairment. Geneva: World Health Organization; 2021. Available from: https://www.who.int/news-room/fact-sheets/detail/blindnessand-visual-impairment. [Last accessed on 2021 Oct 05].

2. Anwar M, Johanson G. Mobile phones and the well-being of blind micro-entrepreneurs in Indonesia. Electron J Inf Syst Dev Ctries. 2015;67(1):1-18. https://doi.org/10.1002/j.1681-4835.2015. tb00481.x

3. Hughes K, Bellis MA, Hardcastle KA, Sethi D, Butchart A, Mikton $\mathrm{C}$, et al. The effect of multiple adverse childhood experiences on health: A systematic review and metaanalysis. Lancet Public Health. 2017;2(8):e356-66. https://doi. org/10.1016/S2468-2667(17)30118-4

PMid:29253477

4. Walsh K, Galea S, Koenen KC. Mechanisms underlying sexual violence exposure and psychosocial sequelae: $A$ theoretical and empirical review. Clin Psychol Sci Pract. 2012;19(3):260-75. https://doi.org/10.1111/cpsp.12004

PMid:25762853

5. Zegeye TG. An investigation on the status of resilience amongst adults with blindness in Addis Ababa. Afr J Disabil. 2020;9:628. https://doi.org/10.4102/ajod.v9i0.628

PMid:33240799

6. Azumah FD, Krampah S, Nachinaab JO, Asante SS. Genderbased violence against persons with visual impairment and their coping strategies in Kumasi metropolis, Ghana. J Disabil Stud. 2019;5(1):16-23.

7. Gebreselassie L. Sexual Harassment against Women with Visual Impairment in Addis Ababa: Types, Extent and Consequences. Ethiopia: Thesis, Addis Ababa University, Ethiopia; 2017.

8. Anosike P, Ehrich LC, Ahmed P. Phenomenology as a method for exploring management practice. Int $\mathrm{J}$ Manag Pract. 2012;5(3):205-24. https://doi.org/10.1504/IJMP.2012.048073

9. Giorgi A. The descriptive phenomenological psychological method. J Phenomenol Psychol. 2012;43(1):3-12. https://doi. org/10.1163/156916212X632934

10. Tadesse T, Asmare A, Ware H. Exploring teachers' lived experiences of cooperative learning in Ethiopian higher education classrooms: A phenomenological-case study. Educ Sci. 2021;11(7):332. https://doi.org/10.3390/educsci11070332

11. Jabbari J, Duncan G. Forming 'men for others': A phenomenological case study on the intersection of school culture and at-risk males. Int Stud Cathol Educ. 2021;1-19. https://doi.org/10.1080/19422539.2020.1858637

12. Broome RE. Descriptive Phenomenological Psychological Method: An Example of a Methodology Section from Doctoral Dissertation. San Fransico: Saybrook University; 2011. Available from: http://www.phenomenologyblog.com/ wp-content/uploads/2012/04/broome-2011-phenomenologicalpsychological-dissertation-method-chapter.pdf. [Last accessed on 2021 Oct 01].

13. Dewi NS, Jittanoon P, Wiroonpanich W. Parental challenges in promoting the well-being of talented youths in Indonesia: A phenomenological study. Nurse Med J Nurs. 2021;11(2):2. https://doi.org/10.14710/nmjn.v11i2.34258

14. World Health Organization. Understanding and Addressing Violence against Women. Geneva: World Health Organization; 2012. Available from: http://apps.who.int/iris/bitstream/
handle/10665/77434/WHO_RHR_12.37_eng.pdf.

[Last accessed on 2021 Oct 05].

15. Mezey G, King M. The effects of sexual assault on men: A survey of 22 victims. Psychol Med. 1989;19(1):205-9. https:// doi.org/10.1017/S0033291700011168

16. Haskell SG, Gordon KS, Mattocks K, Duggal M, Erdos J, Justice A, et al. Gender differences in rates of depression, PTSD, pain, obesity, and military sexual trauma among Connecticut war veterans of Iraq and Afghanistan. J Womens Health. 2010;19(2):267-71. https://doi.org/10.1089/jwh.2008.1262 PMid:20109115

17. Kelly UA, Skelton K, Patel M, Bradley B. More than military sexual trauma: Interpersonal violence, PTSD, and mental health in women veterans. Res Nurs Health. 2011;34(6):457-67. https://doi.org/10.1002/nur.20453

PMid:21898452

18. Newins AR, Glenn JJ, Wilson LC, Wilson SM, Kimbrel NA, Beckham JC, et al. Psychological outcomes following sexual assault: Differences by sexual assault setting. Psychol Serv. 2021;18(4):504-11. https://doi.org/10.1037/ser0000426 PMid:32271049

19. Bryant-Davis $T$, Chung $H$, Tillman $S$. From the margins to the center: Ethnic minority women and the mental health effects of sexual assault. Trauma Violence Abuse. 2009;10(4):330-57. https://doi.org/10.1177/1524838009339755

20. Brady $S$. The impact of sexual abuse on sexual identity formation in gay men. J Child Sex Abuse. 2008;17(3-4):359-76. https:// doi.org/10.1080/10538710802329973 PMid: 19042606

21. Forsman RL. Prevalence of sexual assault victimization among college men, aged 18-24: A review. J Evid Inf Soc Work. 2017;14(6):421-32. https://doi.org/10.1080/23761407.2017.136 9204

PMid:28895801

22. Masho SW, Anderson L. Sexual assault in men: A populationbased study of Virginia. Violence Vict. 2009;24:98-110. https:// doi.org/10.1891/0886-6708.24.1.98

23. Davies M. Male sexual assault victims: A selective review of the literature and implications for support services. Aggress Violent Behav. 2002;7(3):203-14. https://doi.org/10.1016/ S1359-1789(00)00043-4

24. Hodge $L$, Privott $C$. The impact of sexual assault on college students' daily occupations: A phenomenological approach. Occup Ther Ment Health. 2020;36(3):258-69. https://doi.org/10. 1080/0164212X.2020.1772167

25. Stewart KE, Du Mont J, Polatajko HJ. Applying an occupational perspective to women's experiences of life after sexual assault: A narrative review. J Occup Sci. 2019;26(4):546-58. https://doi. org/10.1080/14427591.2018.1516159

26. Stewart KE, Charise A, Polatajko HJ, Du Mont J. The aftermath and the aftermyth: Learning from memoirists who experienced sexual assault while at university. Qual. Health Res. 2020;30(10):1572-83. https://doi.org/10.1177/1049732320922516

27. Twinley R. The Perceived Impacts of Woman-to-woman Rape and Sexual Assault, and the Subsequent Experience of Disclosure, Reaction, and Support on Victim/Survivors' Subjective Experience of Occupation. Plymouth: Playmouth University, UK; 2016.

28. Twinley R. Woman-to-woman rape and sexual assault, and its impact upon the occupation of work: Victim/survivors' life roles of worker or student as disruptive and preservative. Work. 2017;56(4):505-17. https://doi.org/10.3233/WOR-172529 PMid:28409768

29. Twinley R. An interview with "Lucy": A survivor of woman-towoman rape. J Occup Sci. 2012;19(2):191-5. https://doi.org/10. 


\section{0/14427591.2011.607793}

30. Chamsi-Pasha M, Chamsi-Pasha $\mathrm{H}$. A review of the literature on the health benefits of Salat (Islamic prayer). Med J Malaysia. 2021;76(1):93-7.

PMid:33510116

31. Rahmat M, Yahya MW. Trials of the Islamic education learning model in Indonesian universities: A sufistic approach as an alternative. Int J High Educ. 2021;10(2):253-64.

32. Saniotis A. Understanding mind/body medicine from Muslim religious practices of Salat and Dhikr. J Relig Health. 2018;57(3):849-57. https://doi.org/10.1007/s10943-014-9992-2 PMid:25613191

33. Yucel S. The Effects of Prayer on Muslim Patients' Well-being, May; 2007. Available from: https://hdl.handle.net/2144/40. [Last accessed on 2021 Oct 1].

34. Smith LB, Lenz AS, Strohmer D. Differential prediction of resilience among individuals with and without a history of abuse. Couns Values. 2017;62(1):106-22. https://doi.org/10.1002/ cvj. 12052.

35. Marriott C, Hamilton-Giachritsis C, Harrop C. Factors promoting resilience following childhood sexual abuse: A structured, narrative review of the literature. Child Abuse Rev. 2014;23(1):17-34. https://doi.org/10.1002/car.2258

36. Fung J, Wong MS, Park $\mathrm{H}$. Cultural background and religious beliefs. In: Sanders MR, Morawska A, editors. Brisbane: The Registered Company. Switzerland AG: Springer Nature; 2018. p. 469-485. https://doi.org/10.1007/978-3-319-94598-9

37. Campbell R, Dworkin E, Cabral G. An ecological model of the impact of sexual assault on women's mental health. Trauma Violence Abuse. 2009;10(3):225-46. https://doi. org/10.1177/1524838009334456

PMid:19433406

38. Cohen S, Wills TA. Stress, social support, and the buffering hypothesis. Psychol Bull. 1985;98(2):310-57. https://doi. org/10.1037/0033-2909.98.2.310 PMid:3901065

39. Elzy MB. Examining the relationship between childhood sexual abuse and borderline personality disorder: Does social support matter? J Child Sex Abuse. 2011;20(3):284-304. https://doi.org/ 10.1080/10538712.2011.573526 PMid:21660815

40. Evans SE, Steel AL, DiLillo D. Child maltreatment severity and adult trauma symptoms: Does perceived social support play a buffering role? Child Abuse Negl. 2013;37(11):934-43. https:// doi.org/10.1016/j.chiabu.2013.03.005

\section{PMid:23623620}

41. HymanSM, Gold SN, CottMA. Forms of social supportthatmoderate PTSD in childhood sexual abuse survivors. J Fam Violence. 2003;18(5):295-300. https://doi.org/10.1023/A:1025117311660

42. Korol S. Familial and social support as protective factors against the development of dissociative identity disorder. J Trauma Dissoc. 2008;9(2):249-67. https://doi. org/10.1080/15299730802048744

PMid:19042777

43. Murthi M, Espelage DL. Childhood sexual abuse, social support, and psychological outcomes: A loss framework. Child Abuse Negl. 2005;29(11):1215-31. https://doi.org/10.1016/j. chiabu.2005.03.008

PMid:16260039

44. Pepin EN, Banyard VL. Social support: A mediator between child maltreatment and developmental outcomes. J Youth Adolesc. 2006;35(4):612-25. https://doi.org/10.1007/s10964-006-9063-4

45. Sperry DM, Widom CS. Child abuse and neglect, social support, and psychopathology in adulthood: A prospective investigation. Child Abuse Negl. 2013;37(6):415-25. https://doi.org/10.1016/j. chiabu.2013.02.006

PMid:23562083

46. Sable MR, Danis F, Mauzy DL, Gallagher SK. Barriers to reporting sexual assault for women and men: Perspectives of college students. J Am Coll Health. 2006;55(3):157-62. https:// doi.org/10.3200/JACH.55.3.157-162

PMid:17175901

47. Reitz-Krueger CL, Mummert SJ, Troupe SM. Real men can't get raped: an examination of gendered rape myths and sexual assault among undergraduates. J Aggress Confl Peace Res. 2017;9(4):314-23. https://doi.org/10.1108/ JACPR-06-2017-0303

48. McLean IA. The male victim of sexual assault. Clin Asp Sex Violence. 2013;27(1):39-46. https://doi.org/10.1016/j. bpobgyn.2012.08.006

49. Mehrolhassani MH, Yazdi-Feyzabadi V, Mirzaei S, Zolala F, Haghdoost AA. Oroomiei N. The concept of virginity from the perspective of Iranian adolescents: A qualitative study. BMC Public Health. 2020;20(1):717. https://doi.org/10.1186/ s12889-020-08873-5 PMid:32429891

50. Saharso S. Hymen "repair": Views from feminists, medical professionals and the women involved in the Middle East, North Africa and Europe. Ethnicities. 2022;2022:14687968211061582. https://doi.org/10.1177/14687968211061582 